\title{
Project of revitalisation of the area next to the Potocki family Palace in Lublin
}

\author{
Patryk Krupiński, Krystyna Pudelska \\ e-mail: kpudelsk@autograf.pl \\ Department of Ornamental Plants, Dendrology and Landscape Architecture \\ Faculty of Horticulture and Landscape Architecture, University of Life Science in Lublin \\ Gtęboka 28, 20-612 Lublin, Poland
}

\begin{abstract}
The old baroque palace of the Potocki family is located in the heart of Lublin. In 1967 it was entered in the register of Lubelskie voivodeship under the number A/236. Nowadays, this historic building requires a thorough reconstruction and its surroundings - revitalisation. The aim of this study is to suggest a concept of land development around the palace taking into consideration the contemporary needs of its users.
\end{abstract}

Key words: project of revitalisation, the Potocki family Palace, Lublin

\section{Introduction}

The idea of revitalisation refers to all actions which aim at the recovery of devastated areas, which lost their original functions, using specific conditionality and the potential of a given place [Dz. U. 2015 poz. 1777]. It includes planning, conservation, economic and social activities aiming at functional and practical improvement of devastated places [Kołacz i Wielgus 2015]. Revitalisation of urban spaces is connected with preservation, protection of historic and contemporary forms and protection and planning of major elements of nature [Przesmycka 2005]. It is multifaceted process which according to the vision of the 21 century [Nowa Karta Ateńska 2003] cities leads to the improvement of 'the quality of contemporary urban spaces, their esthetic, functionality, safety and something of the openness to socialisation of city life' [Fornagiel 2012].

In revitalisation process social participation plays a major role, which gives a society the feeling of involvement in the issues of the local environment, codecision about the space changes, the protection of cultural heritage and shaping a new space and city and region identity [Hausner 1999, Przesmycka 2008B, Pawłowska 2010].

Since the 90s of the previous century, revitalisation activities in Lublin have been conducted very intensely [Niećko and Boguszewski 2005]. They cover about 60 devastated places such as The Parish Church Square, the former Church of the Most Sacred Heart and the Visitation of the Virgin Mary, the monastic complex of the Nuns of the Visitation in Lublin (present-day the Centre of Culture) or the park on Peowiaków Street. The development and revitalisation programme for Lublin planned between the years 2017-2023 adopted by the Council of Minister as an economic programme within the meaning of point 6 of Article 18(2) of 8 March 1990 is a continuation of activities initiated in previous years [http.1].

In the years 2016-2017 one of the activities of Lublin centre recovery was revitalisation of Litewski Square and a nearby area at the former Czartoryski family Palace (present-day the head office of Polish Academy of Sciences). The buildings went a thorough reconstruction gaining new social and cultural functions. Reconstruction also included changing the road traffic arrangement (enlarging the area of the place) and giving this place more representative function.

In the neighbourhood of Litewski Square and the Czartoryski family Palace there is another historic building of great architectural values, the former Potocki family Palace. Since 1967 it has been under conservational protection and it is on the list of historic buildings of Lubelskie voivodeship. The building which is situated in 
the heart of the city, seriously threatened for many years, requires immediate conservational activites. Frequent changes of the owners who were the users of the palace, resulted in the destruction of Lublin residence of the Potocki family. The building is suffering damage and it requires a thorough reconstruction and its surroundings (entrance courtyard and the northern part - the former garden) putting in order and defining its new function.

The project of land development at the Potocki family Palace, presented in this paper, constitutes a concept which can serve the society while at the same time it focuses on historic and cultural values of one of the historic buildings perceived as a landmark for Lublin inhabitants.

\section{Localisation of the palace and methods}

The Potocki family Palace is situated in Lublin at 3 Staszica Street on a rectangular shape plot with the area of $2365 \mathrm{~m}^{2}$ (including green areas $-60 \mathrm{~m}^{2}$ ). The area discussed in the paper covers the main courtyard from the south and the square - the area of the former garden in the north (fig. 1).

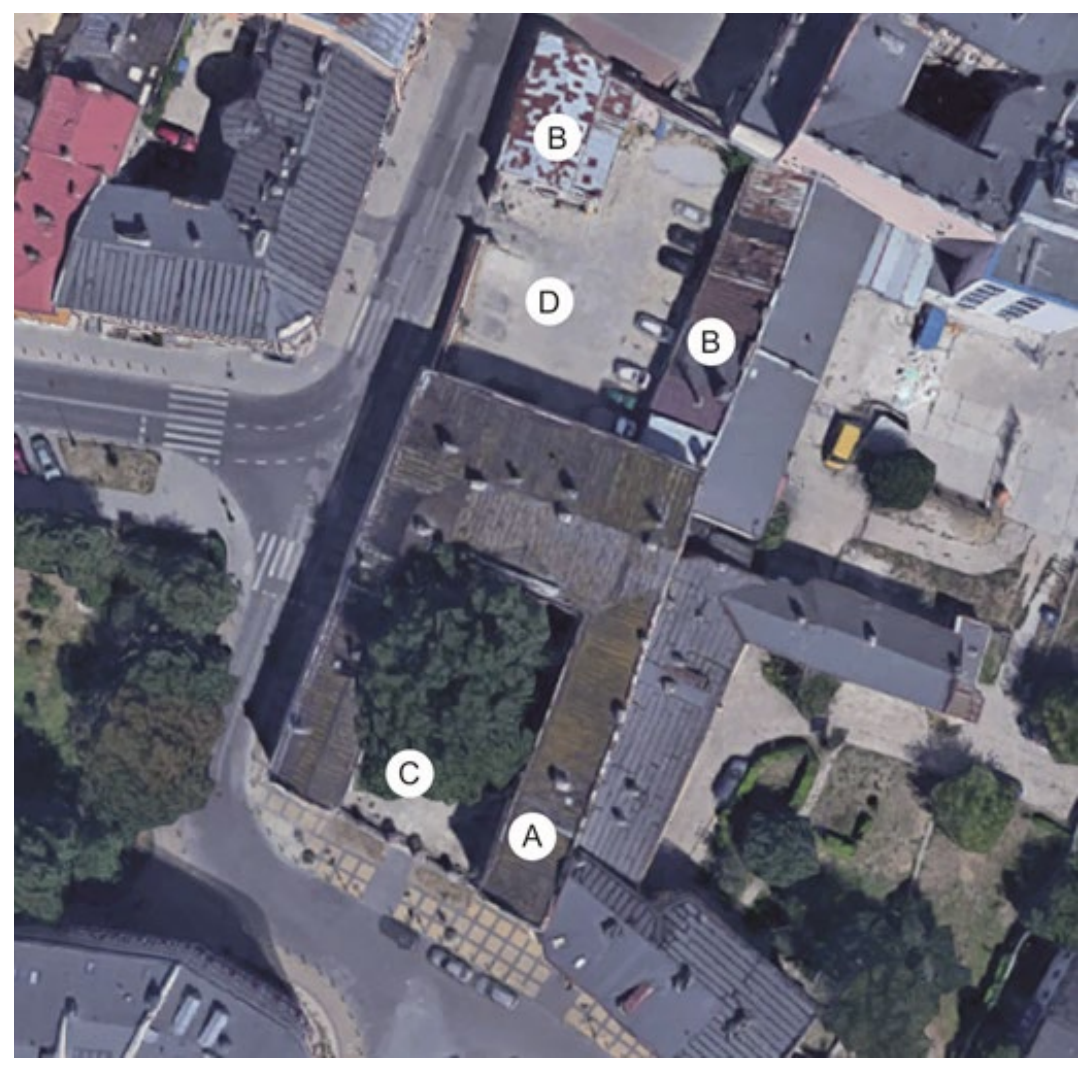

Fig. 1. The satellite view on the area of the Potocki family Palace in Lublin - the state from 2017. A - Palace, B - Front courtyard of the Palace, C-Parking, D-Garage. Widok satelitarny na teren Pałacu Potockich w Lublinie - stan z 2017 roku (www.google.pl/maps [19.03.2017]). A - Pałac, B - Dziedziniec główny Pałacu, C - Parking, D - Garaże.

The research was initiated by the search of literature sources connected with the history of Lublin and the Potocki family Palace including archive maps, single and dispersed texts from the County State Archive in Lublin. In 2016 there was conducted a detailed inventory of trees and bushes growing in the discussed area. During the research the height of the trees was measured with the use of the altimeter SUUNTO PM-5/1520, the volume of the tree trunk at the height of $130 \mathrm{~cm}$ above the ground and the height of the bushes. At the diameter of a tree crown there was used a method of projecting of two the most extreme points of a tree crown on the surface. The names of the taxons were used following Seneta and Dolatowski (2011). The age of the trees was identified using the table of age structure of trees developed by Majdecki (1980/1986). Field studies referred to the localisation of the present buildings on the discussed area. Photographic documentation was added to research works. 


\section{The history of the Potocki family Palace in Lublin}

The Potocki family Palace in Lublin was built in the years 1719-1730 when it belonged to Jerzy Potocki who was the Capitan of the Polish Army of the Polish Third Republic [Studziński, Michalak and Jodłowska 2006]. Originally, the baroque palace consisted of the storied main body and two ground floor side wings connected with it ( from the east and the west). The layout was based on a scheme of a horseshoe with a representative front courtyard in Italian style situated from the south. The courtyard was closed by a semicircular wall with bars and the entrance gate [Michalak and Jodłowska 2006]. The continuation of the axes of the palace and garden complex, was the road leading to Krakowskie Przedmieście ('present-day' the beginning of Staszica Street, fomer Poczętkowska Street). From the east of the palace there were located garden areas (fig. 2) and from the courtyard side on the storey of the building there was an open porch with five arcades (fig. 3). In 1747 the youngest son of Jerzy, Eustachy Potocki, the Marshal of the Crown Tribunal in Lublin, became the owner of the palace and he decided to enlarge it in the years 1752-1755. Probably the person responsible for the reconstruction could be Jakub Fontana - Polish architect of Italian origin, who worked for Eustachy Potocki [Gawarecki 1957]. Probably the building was enriched with a mansard roof with dormers, covered with tiles and the side outbuildings with shingle [Michalak and Jodłowska 2006]. In the palace there were richly decorated tiled stoves, panelling and golden slates and decorations. The room walls were covered with colourful materials with dominating plant motifs typical for the architecture of the $18^{\text {th }}$ century. The furnishings were Gdansk chairs covered with leather, mirrors in brass and walnut frames [Inventory Palace from 1783 year behind: Michalak and Jodłowska 2006, Studziński 1994].

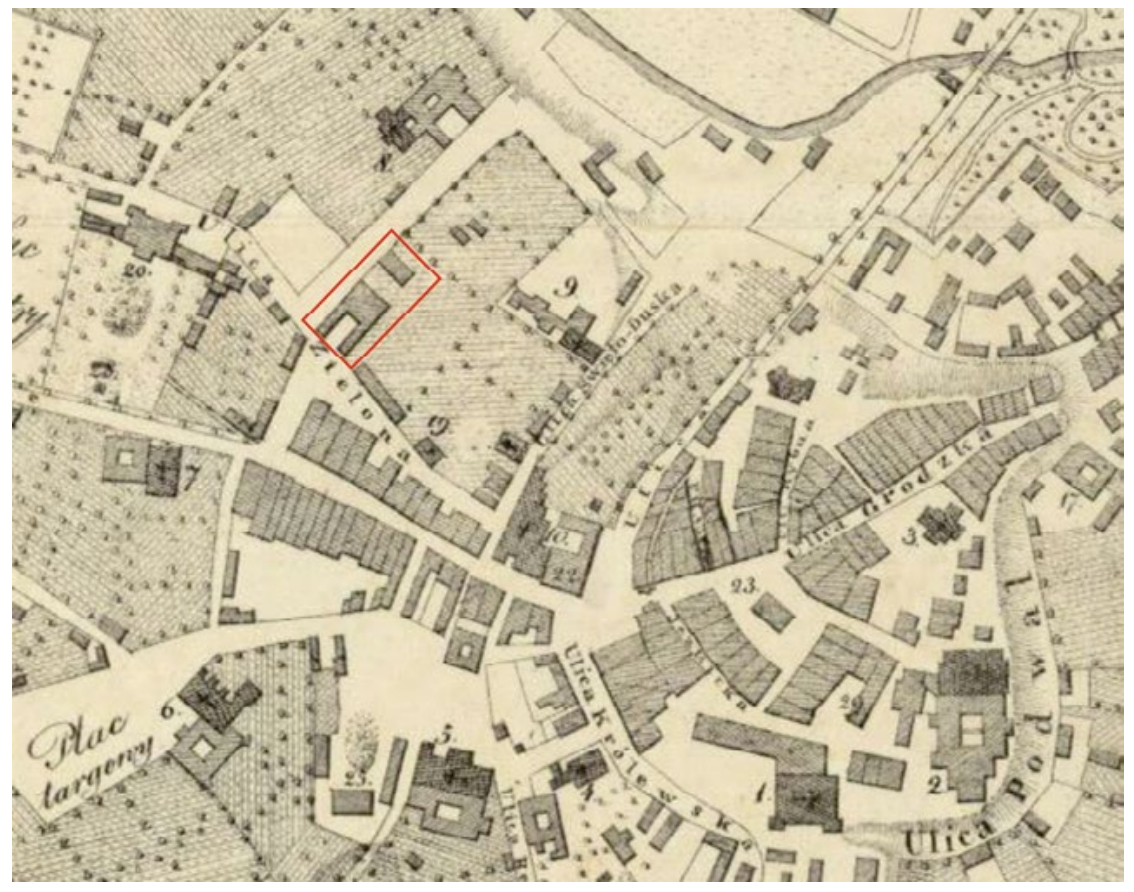

Fig. 2. A part of Lublin map from 1829 (www.stareplanymiast.pl). Former Potocki family Palace.

Fragment mapy Lublina z roku 1829 (www.stareplanymiast.pl). Dawny Pałac Potockich.

In 1789 Jan Nepomucen, the son of Eustachy Potocki handed the Lublin Palace over to State Treasury. Since that time the building has changed its functions and has been redecorated several times. In 1790 it was the quarters of a Polish cavalry and in 1792 during the time of Austrian occupation it was a prison. At this time the layout of the palace rooms was changed, the windows were reduced in size and the side decorations of the windows were removed the same as an open porch on the storey and the 'semicircular fence line closing the courtyard from the south was replaced with the present fence' [Michalak and Jodłowska 2006] (fig. 4 and 5).

After the First World War the building was used as the main Police Headquarters in Lublin. In the next years it was eg. the quarters of the Branch of the Citizens Police or Special Vocational School and since 1994 it has belonged to the Catholic University of Lublin. In 2016 it fell into the hands of a private owner [http. 2]. 

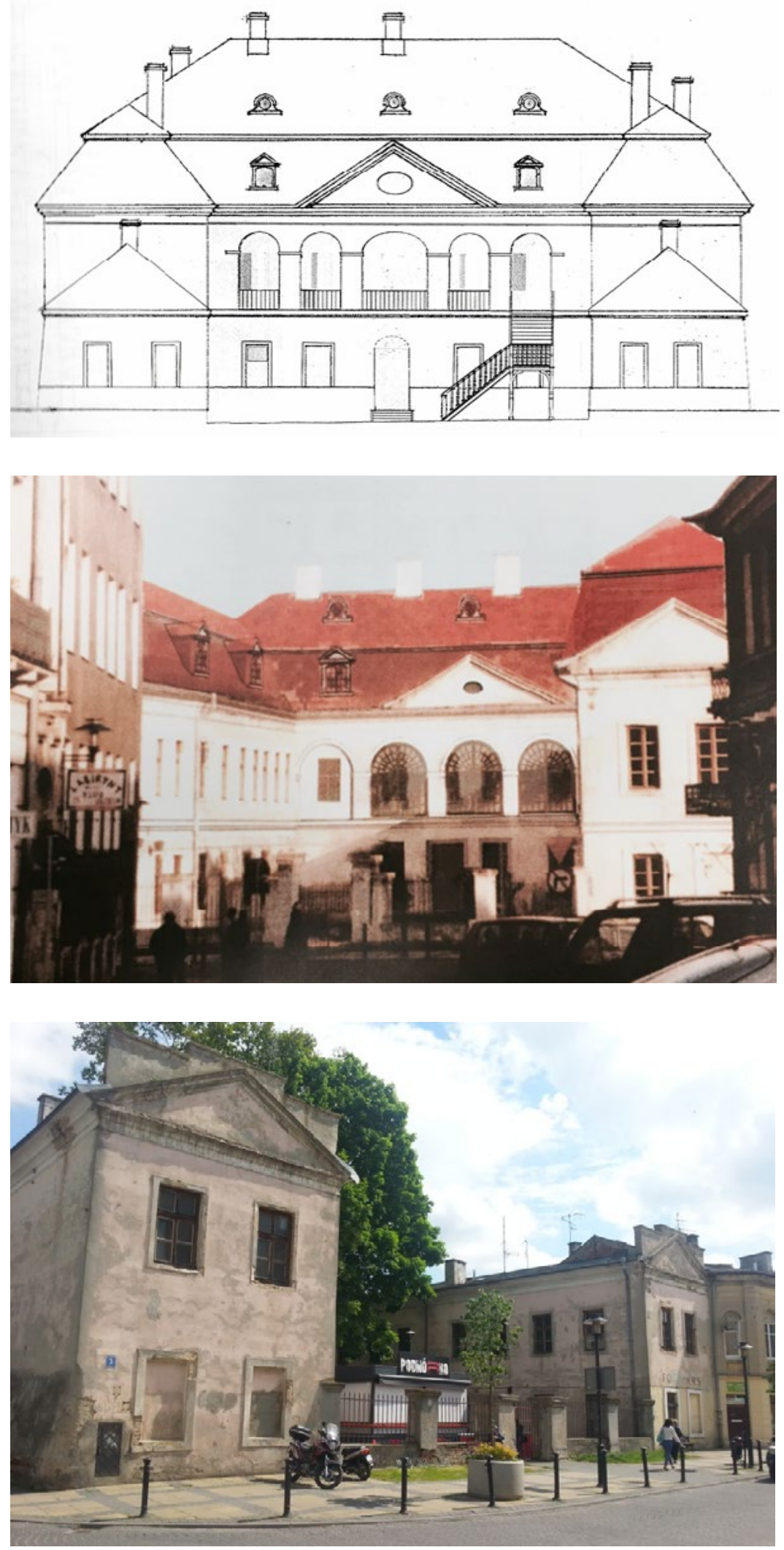

Fig. 3. Front facade of the palace from the $18^{\text {th }}$ century. Figure author is A. Zwierzchowski (2006).

Elewacja frontowa pałacu z okresu XVIII wieku. Autorem ryciny jest A. Zwierzchowski (2006).

Fig. 4. View to front facade on the Potocki family Palace. Photography presents the reconstruction of the palace facade from the $18^{\text {th }}$ century (dziennikwschodni.pl).

Widok od frontu na Pałac Potockich. Fotografia przedstawia rekonstrukcję elewacji pałacu z XVIII wieku (dziennikwschodni.pl)

Fig. 5. Photography showing the current fence of the yard (P. Krupiński 2017).

Fotografia przedstawiająca obecne ogrodzenie dziedzińca (P. Krupiński 2017). 


\section{The present state of the research area}

\section{Legal and ownership conditions of the building}

At present the discussed research area belongs to a private investment company-Building Investment. After a series of reconstructions and transformations, the palace and its surroundings lost its character of a magnate residence. A current owner is going to adopt a historic building to a hotel [http. 3].

\section{Inventory and dendrological analysis}

Dendrological inventory conducted in 2016 shows that in this area there grow 6 plants. These are two trees: Norway Maple (Acer platanoides L.) and English Oak (Quercus robur L.) and four bushes of Common Lilac (Syringa vulgaris $L$.) (tab. 1, fig. 6). Inventoried species grow on the front courtyard, they are in good condition and they do not need any special care. The age of a Norway Maple is about 120 and English Oak is over 150. It can be estimated that these trees come from the period when the building was a prison. Large tree crown of a Norway Maple and a Common Oak considerably limit the light to the courtyard.

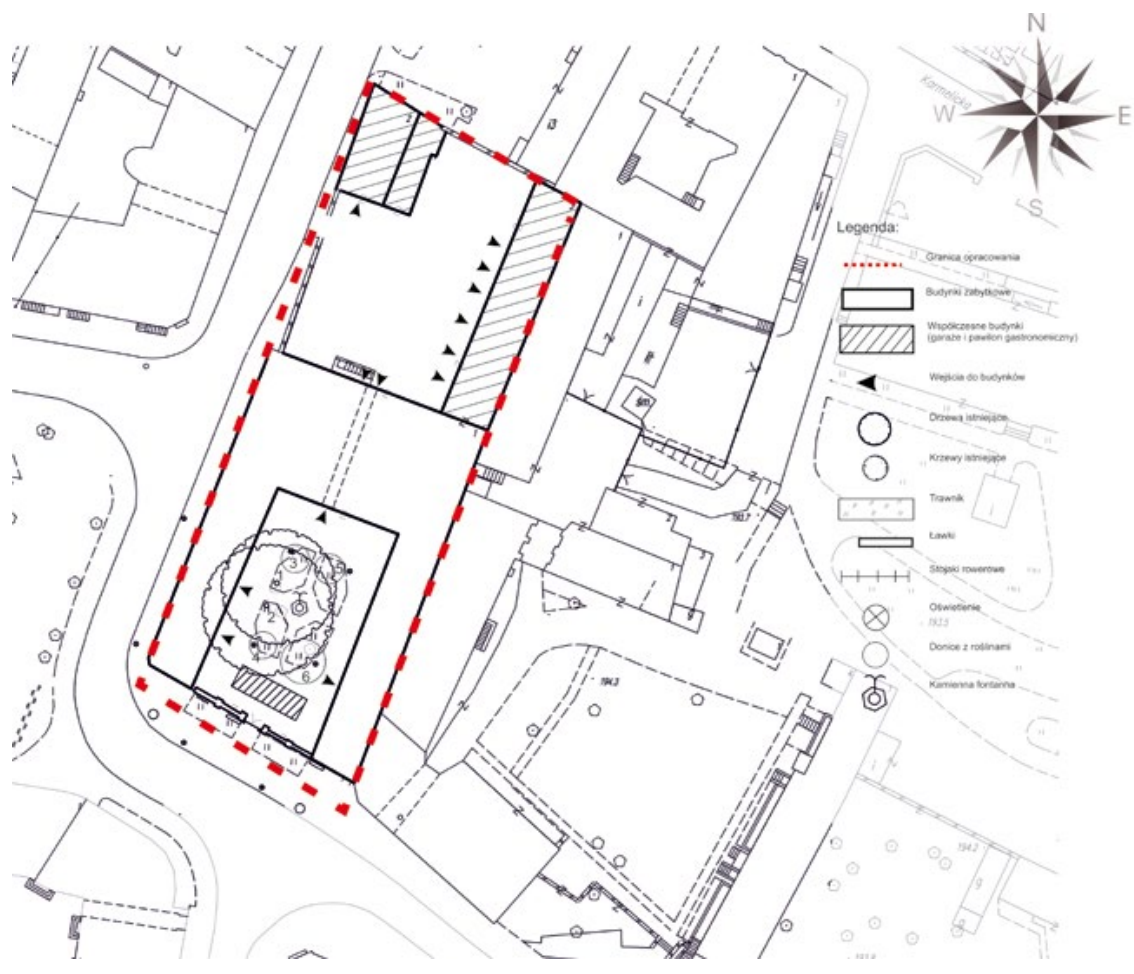

Fig. 6. Inventory of the discussed area by (P. Krupiński 2017).

Inwentaryzacja terenu opracowania oprac. (P. Krupiński 2017).

Table 1. Dendrological inventory of trees and bushes growing on the area under discussion (2016). Inwentaryzacja dendrologiczna drzew i krzewów rosnących na terenie opracowania (2016).

\begin{tabular}{|c|c|c|c|c|c|}
\hline $\begin{array}{l}\text { No. } \\
\text { Lp. }\end{array}$ & $\begin{array}{l}\text { Latin and English } \\
\text { name species } \\
\text { Nazwa łacińska } \\
\text { i angielska gatunku }\end{array}$ & $\begin{array}{c}\text { Diameter } \\
\text { of the crown } \\
\text { Średnica korony } \\
\text { [m] }\end{array}$ & $\begin{array}{c}\text { Trunk } \\
\text { circumference } \\
\text { Obwód pnia } \\
\text { [cm] }\end{array}$ & $\begin{array}{l}\text { Plant height } \\
\text { Wysokość } \\
\text { rośliny } \\
\text { [m] }\end{array}$ & $\begin{array}{c}\text { Comments } \\
\text { Uwagi }\end{array}$ \\
\hline 1. & $\begin{array}{l}\text { Acer platanoides L. } \\
\text { Norway Maple }\end{array}$ & 17 & 200 & 11 & \\
\hline
\end{tabular}




\begin{tabular}{|c|c|c|c|c|c|}
\hline 2. & $\begin{array}{l}\text { Quercus robur L. } \\
\text { English Oak }\end{array}$ & 15 & 280 & 12 & \\
\hline 3. & $\begin{array}{l}\text { Syringa vulgaris L. } \\
\text { Common Lilac }\end{array}$ & 3.7 & 60 & 3 & \\
\hline 4. & $\begin{array}{l}\text { Syringa vulgaris L. } \\
\text { Common Lilac }\end{array}$ & 3.6 & 60 & 4 & \\
\hline 5. & $\begin{array}{l}\text { Syringa vulgaris L. } \\
\text { Common Lilac }\end{array}$ & 4 & 60 & 3 & \\
\hline 6 & $\begin{array}{c}\text { Syringa vulgaris L. } \\
\text { Common Lilac }\end{array}$ & 6 & 70 & 3 & $\begin{array}{l}2 \text { stems } \\
2 \text { pnie }\end{array}$ \\
\hline
\end{tabular}

\section{Compositional analysis, cultural values of the building and its surroundings}

The area under discussion has a central layout with a palace building and two outbuildings - shaped in U letter- and with the main compositional axis running across the centre of the main body of the palace, the courtyard closed from the front with a fence and a gate and towards the south along Staszica Street to Krakowskie Przedmieście Street. From the south and north side of the Potocki family Palace there are interiors geometrical in shape. From the south, on the courtyard, there are two trees and the focus is on the stone fountain situated in the centre. The negative side of this interior is a neglacted elevation of the building, damaged surface and a restaurant (open in summer) situated on the axis of the complex and limiting the view to the south. The north side is a parking and it is the most damaged part of the whole complex. The east side is closed by brick one storey buildings used as garages and utility rooms. The interior courtyard is unattractive and inconsistent with the former magnate residence.

The Potocki family Palace in Lublin is a valuable building with great historic values situated in the heart of the city. On the basis of the decision of 28 February 1967 it was entered in the register of Lubelskie voivodeship under the number $A / 236$. A series of reconstructions, eg. destruction of window decorations as a result of reducing the size of the windows and including the building in the frontage development of Zielona Street resulted in the lost of its residential style. The only decorations left are tympanons on the top walls of the outbuildings and the attics above them [Szymula 2014]. However, the Potocki family Palace called ' The Old Jail' is still an important and recognisable (by Lublin inhabitants ) place in the heart of the city. In its vicinity there are some other buildings of a great cultural value under conservatory protection, eg. the Czartoryski family Palace ( in the register of Lubelskie voivodeship under the number A/225), the Lubomirski family Palace (No A/480 and A/509), the Church of the Immaculate Conception of the Blessed Virgin Mary at Staszica Street (No A/240) or the Church of St. Joseph ( former Greek Monastery ) at Zielona Street (No A/238) and a tenement house of Europa Hotel (No A/502). Besides, the discussed building borders directly with a historic architectural and urban Lublin complex having the status of Historic Monument (since 2007). The area of Historic Monument covers the most important historic buildings in Lublin of special historic, scientific, artistic values and the places worth visiting. That is why the Potocki family Palace after its reconstructions which are the result of different functions of the building, should be available to tourists the inhabitants of Lublin [http. 3].

\section{Revitalisation concept of the area next to the potocki family palace}

The main aim of the presented project is to raise the importance of the building by making it visible and introducing two interiors inspired by the styles of Italian gardens. The project is based on geometrical layout of squares, both in representative interior from the south as well as in the north side, designed as a meeting and relaxation place of the building users, tourists and inhabitants (fig. 7). From the south side in the place of a former courtyard, more representative entrance zone which highlights the values of the building seen from Krakowskie Przedmieście Street is proposed. Reconstructed squares are shaped as a boxwood hedge line. Inside 
the squares there are flowering plants: rambler roses of large, pink flowers - 'Bonica 82' or 'Diadem' species, lavender (Lavendula angustifolia L.) and hosta (Hosta), periwinkle (Vinca minor), ivy (Hedera helix) under the tree crowns (fig. 7).

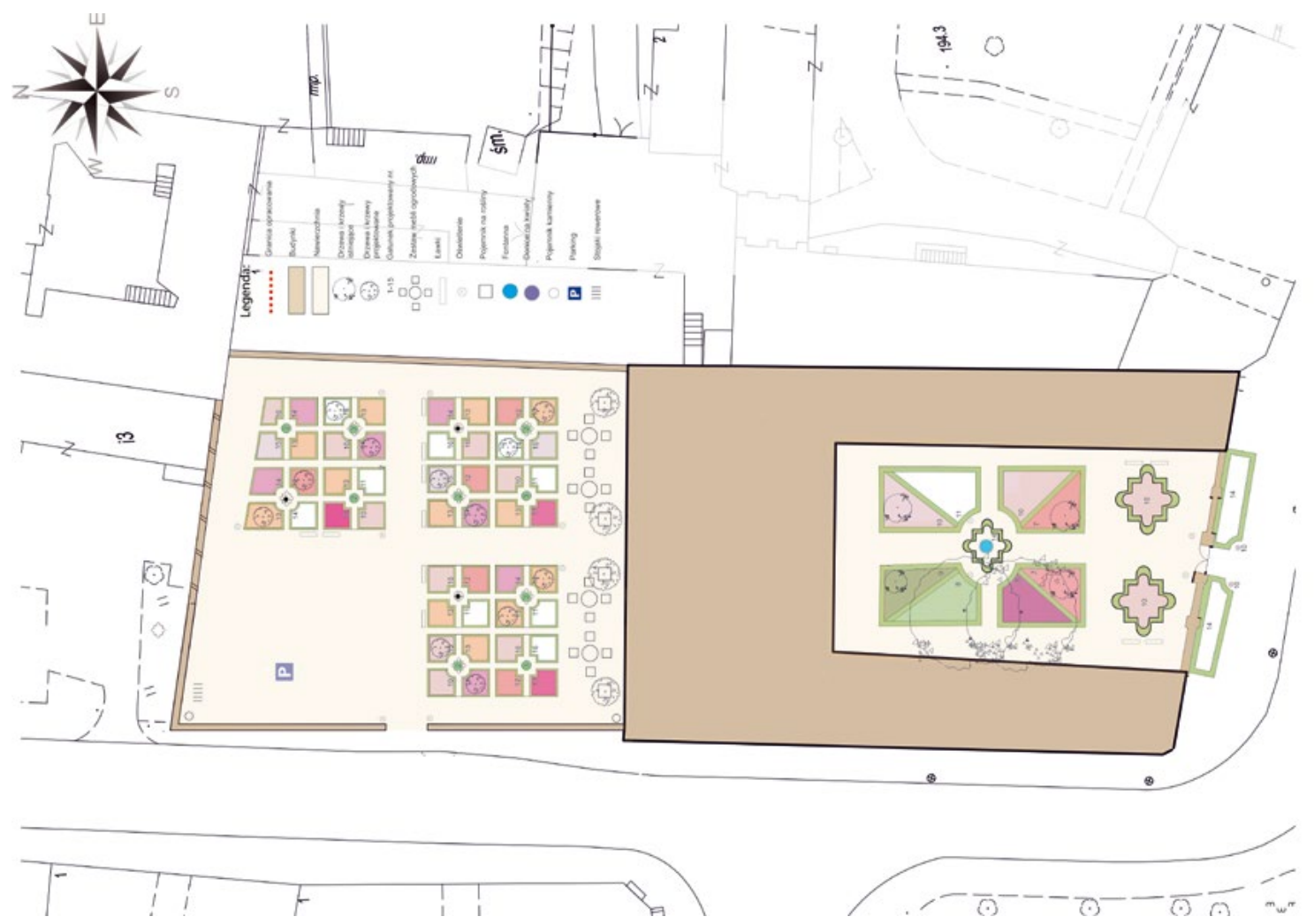

Fig. 7. Suggested concept project of land development by (P. Krupiński 2017).

Proponowany projekt koncepcyjny rewitalizacji terenu oprac. (P. Krupiński 2017).

In the north part, at the entrance to the building, a place for a garden cafe is suggested. In this place a decorative element will be plant pots with Corall Bell 'Green spice' (Heuchera 'Green spice'), Bridgewort (Astibile japonica or Astibile arendsi) which will give pastel shades to the garden in summer and autumn. This part can have some additional benches, eg. stone seats, sculptures or the containers with some species which can be formed (eg. laurel noble - Laurus nobilis L.). In both courtyards, paving stone which would match with the elevation of the building is suggested.

\section{Conclusion}

Revitalisation of the area next to the Potocki family Palace in Lublin is a step towards the recovery of the building "disappearing" from the city map and strongly connected with its history. A new layout and the function of the surroundings next to the historic building and its furnishings is to revive the role of its separate interiors and allow to use them according to the requirements ot its future users. The suggested actions will result not only in the economic benefits, but most of all, they will improve the quality of the central urban space making it more attractive. The palace requires immediate revitalisation to become a historic building shaping the identity of the city. 

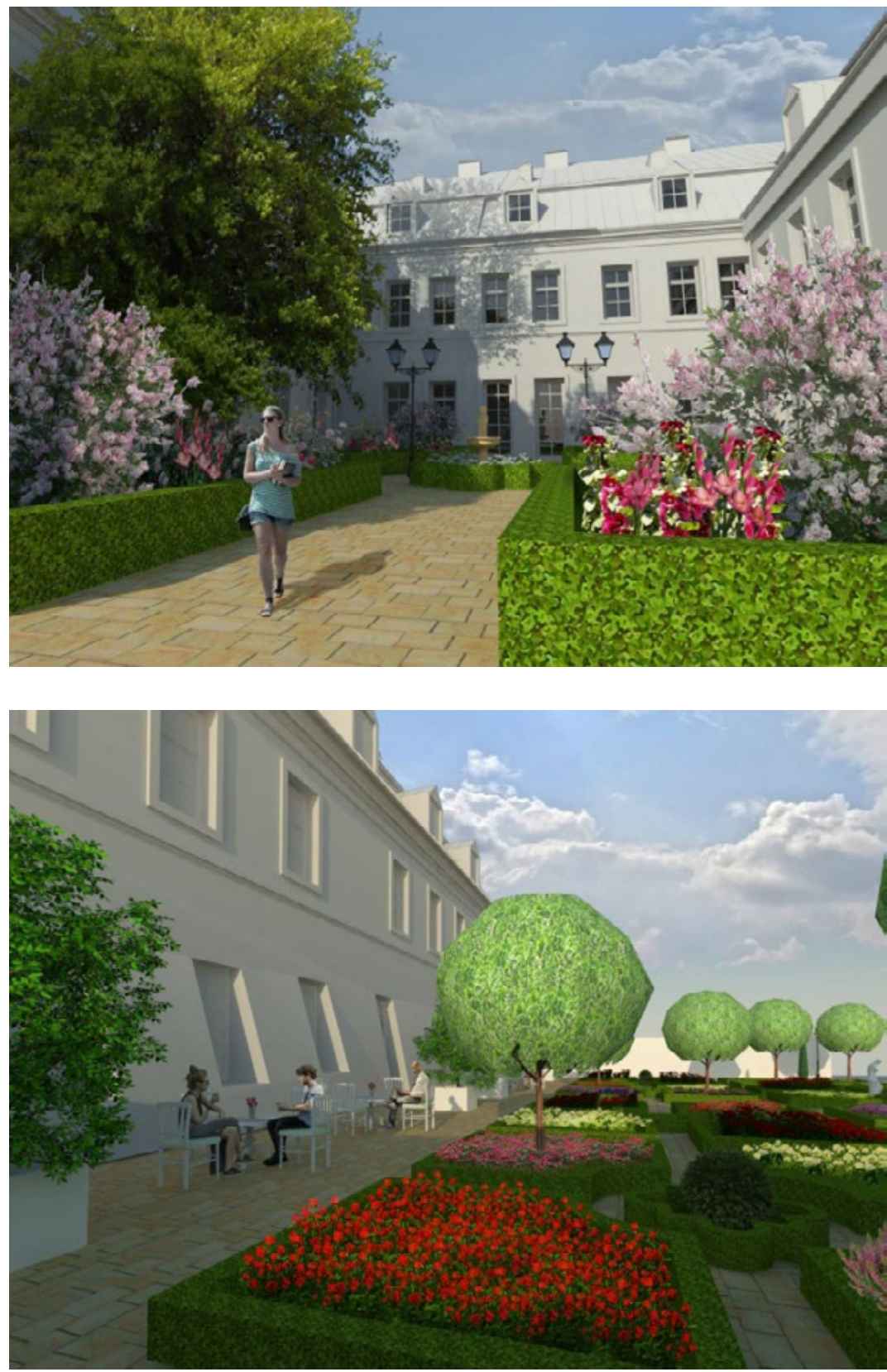

Fig. 8. Visualisation of a front courtyard of the palace edited by (P. Krupiński 2017).

Wizualizacja dziedzińca frontowego Pałacu oprac. (P. Krupiński 2017).

Fig. 9. View on ground floor gardens in the north part of the complex edited by (P. Krupiński 2017).

Widok na partery ogrodowe w północnej części założenia oprac. (P. Krupiński 2017).

\section{References}

[1] Dz. U. 2015 poz. 1777, Ustawa o rewitalizacji z dnia 9 października 2015.

[2] Fornagiel K. 2012. Rewitalizacja miast a potrzeby społeczne. Czasopismo Techniczne Z.12: 182-190.

[3] Gawarecki H. 1957. Pałac Potockich w Lublinie. Kalendarz Lubelski na rok 1958.

[4] Hausner J. 1999. Komunikacja i partycypacja społeczna. Małopolska szkoła administracji publicznej akademii ekonomii w Krakowie, Kraków: 40-42.

[5] Inwentarz z Pałacu z 1783 roku za: Michalak T., Jodłowska E., Zwierzchowski 2006. Pałac Potockich Lublin ul. Staszica 3 Badania architektoniczne na obecność polichromii.

[6] Kołacz P., Wielgus P. 2015. Przepis na rewitalizację. Fundacja dla Uniwersytetu Kazimierza Wielkiego, 6-17. 
[7] Majdecki L. 1980/1986. Tabela wiekowa drzew. Rkps, Oddział Architektury Krajobrazu SGGW, Warszawa

[8] Michalak T., Jodłowska E., Zwierzchowski 2006: Pałac Potockich Lublin ul. Staszica 3 Badania architektoniczne na obecność polichromii. Maszynopis. LWKZ Lublin.

[9] Niećko E., Boguszewski R. 2005. Programy przyrodniczej rewitalizacji miast w strategiach rozwoju regionalnego. Teka Kom. Arch. Urb. Stud. Krajobr.-OL PAN, 68-75

[10] Nowa Karta Ateńska Wizja miast XXI wieku. 2003.

[11] Pawłowska K. 2010. Idea i metody partycypacji społecznej w ochronie krajobrazu i kształtowaniu przestrzeni. Fundacja Partnerstwo dla Środowiska Kraków.

[12] Przesmycka E. 2005. Rewitalizacja przyrodnicza miast-kontynuacja czy dyskontynuacja . Teka Kom. Arch. Urb. Stud. Krajobr.-OL PAN: $53-59$.

[13] Przesmycka E. 2008B. Wschodnie innowacyjne centrum architektury w Lublinie. Teka Kom. Arch. Urb. Stud. Krajobr.-OL PA: $300-310$.

[14] Seneta W., Dolatowski J. 2001. Dendrologia. Wydawnictwo Naukowe PWM Warszawa.

[15] Studziński J. 1994. Kamienica Staszica 3, d. Pałac Potockich d. Stary Kryminał: rozpoznanie historyczne i wnioski konserwatorskie, Opracowane na zlecenie zarządu miasta Lublin, Lublin 1994.

[16] Szymula A. 2014. Pałac Potockich tzw. „Stary Kryminał”, witryna internetowa encyklopedia Lublina (dostęp 12.02.2017); dostępny w Internecie:http://encyklopedialublina.pl/architektura-i-urbanistyka/palace/127-palac-potockich.html.

[17] Zwierzchowski A. (2006). Decyzja LWKZ w Lublinie. IN/4001/LU-20/365/06 z dn.27.01.2006. Wydanie zezwolenia na prowadzenie prac badawczych w budynku dawnego pałacu Potockich przy ul Staszica $3 \mathrm{w}$ Lublinie.

\title{
Internet source
}

[1] http1: Biuletyn informacji publicznej Lublin (dostęp 20.02.2018); dostępny w Internecie: https://bip.lublin.eu/bip/um/ index.php?t=210\&id $=282440$

[2] http2: Dziennik wschodni witryna internetowa (dostęp 10.11.2017) dostępny w Internecie: http://www.dziennikwschodni.pl/lublin/kul-sprzedal-palac-potockich-polsko-wloskiej-spolce-wiadomo-co-bedzie-w srodku,n,1000179282. html http:Strona internetowa Miasta Lublin (dostęp 20.12.2017); dostępny w Internecie:

[3] https://lublin.eu/lublin/przestrzen-miejska/zabytki/zabytki-lublina/zabytki-wpisane-do-rejestru/

\section{Projekt rewitalizacji terenu przy pałacu Potockich w Lublinie}

\begin{abstract}
Dawny barokowy pałac rodu Potockich usytuowany jest w samym centrum Lublina. W roku 1967 został wpisany do rejestru zabytków województwa lubelskiego pod numerem A/236. Obecnie zabytkowa budowla wymaga gruntownej restauracji a jej otoczenie rewitalizacji. Celem pracy jest propozycja zagospodarowania przestrzeni wokół pałacu przy uwzględnieniu współczesnych potrzeb użytkowników.
\end{abstract}

Key words: projekt rewitalizacji, pałac Potockich, Lublin 